у межах наукової школи, що визначається єдністю цілей, завдань, способів діяльності, особливостями поведінки i спілкування, прийнятими членами даного наукового колективу. Норми спілкування та міжособистісні взаємодії дослідників створюють ті ідеали та цінності, які формують образ школи, їі дух, свого роду «міф», без чого, мабуть, неможливе існування школи, іiі самосвідомість, емоційна прихильність, усвідомлення своєї приналежності до школи їі членів, і що відрізняє одну школу від інших. 3 іншого боку, ці ідеали і цінності полегшують узгодження індивідуальних самовизначень дослідників та їх взаємодію і комунікацію в колективі. Дотримуючись своїх наукових традицій і створюючи нові, наукові школи, взаємодіючи в межах розвитку наукового знання, роблять свій внесок у створення і розвиток корпоративної культури. За своєю природою вони стають об’єктивним джерелом іï розвитку.

Перехід на інноваційний шлях розвитку розглядається на сучасному етапі як ключова мета економіки, визнана науковцями, політиками та представниками бізнесу. Головний спосіб іiі досягнення - забезпечення провідної ролі використання в економіці нового знання. Однак способи переходу, позначені в офіційних документах, поки сформульовані переважно у формі стратегічних напрямів. Зрозуміло, що тактика інноваційного розвитку повинна враховувати позитивний досвід організації науки, накопичений раніше. Особливо важливо визначити ті здорові «клітки» наукового організму, які найбільш удало можуть бути адаптованими до нових цілей і сформують ядро нової інституційної структури знання. У цьому сенсі наукові школи становлять унікальне явище, особливо у плані створення людського потенціалу, здатного об'єднувати свої зусилля і координувати спільні дії задля досягнення спільних цілей.

\title{
Література
}

1. Антонов А. Н. Преемственность и возникновение нового знания в науке / А. Н. Антонов. М. : Московский университет, 1985. - 171 с. 2. Внутренние и внешние факторы развития науки (историографический аспект проблемы). - М. : ИНИОН, 1983. - 72 с. 3. Глущенко Л. Ф. Важная форма развития научного потенциала высшей школы - научные школы / Л. Ф. Глущенко, Н. А. Глущенко, Н. Г. Лаптева // Современные наукоемкие технологии. - 2007. - № 3. - С. 49. 4. Грезнева О. Ю. Научные школы (педагогический аспект) / О.Ю.Грезнева - М. : Моск. гуманитар. ун-т, 2003. - 69 с. 5. Леднев В. С. Научное образование: развитие способностей к научному творчеству / В. С. Леднев - М. : МГАУ, 2001. - 120 с. 6. Научная деятельность в системе современной культуры : [сб. науч. трудов]. - Новосибирск : АН СССР, Сиб. отд. Ин-т истории, филологии и философии, 1987. - 242 с. 7. Поппер К. Логика и рост научного знания. Избранные работы / К. Поппер - М. : Прогресс, 1983. - 606 с. 8. Толкачев В. В. Традиция как феномен культуры: философский анализ: дисс. ... к. филос. н. : 09.00.13 / Толкачев Вадим Валерьевич. Ставрополь, 1999. - 155 с.

УДК $371.72: 373.3$

С. М. Кондратюк, кандидат пед. наук, доиент,

Н. М. Павлущенко, кандидат пед. наук, доиент,

О. М. Король, кандидат пед. наук, доиент, Сумський державний педагогічний університет імені А. С. Макаренка

\section{ПРОБЛЕМА НАСТУПНОСТІ ДОШКІЛЬНОЇ І ПОЧАТКОВОЇ ОСВІТИ}

Кондратюк С. М., Павлущенко Н. М., Король О. М. Проблема наступності дошкільної і початкової освіти.

У статті розкрито наукові аспекти наступності дошкільної та початкової освіти, вказується на позитивний вплив наступності в роботі дитячого садка і початкової школи. Розглядаються питання психолого-педагогічної готовності дітей дошкільного віку до навчання у школі та необхідність підготовки педагогічних кадрів до такого роду діяльності. 
Ключові слова: наступність, діти, дошкільний вік, дошкільна і початкова освіта.

Кондратюк С. Н., Павлущенко Н. М., Король О. М. Проблема преемственности дошкольного и начального образования.

В статье раскрываются научные аспекты преемственности дошкольного и начального образования, указывается на позитивное влияние преемственности в работе детского сада и начальной школы. Рассматриваются вопросы о психолого-педагогической готовности детей дошкольного возраста к обучению в школе и о необходимости подготовки педагогических кадров к такому роду деятельности.

Ключевые слова: преемственность, дети, дошкольный возраст, дошкольное и начальное образование.

Condratyuk S. M., Pavluschenko N. M., Corol O. M. The problem of continuity preschool and primary education.

There are questions about the psychological and educational preparation of preschool children for school and the necessity of training teachers for these activities consider in the article. We discover the scientific aspects of continuity pre-school and primary education; show the positive influence from the work of the kindergarten to the primary school.

Key words: continuity, children, preschool age, preschool and primary education.

Дошкільна освіта $є$ необхідним складником системи безперервної освіти, вона своєрідна освітня ланка, яка має своє призначення, характерні цілі і завдання. Стрімке сьогодення поставило перед дошкільною освітою та вихованням актуальне завдання орієнтуватися на світовий рівень формування творчої особистості, яка житиме i працюватиме в умовах конкуренції знань, умінь, навичок. Тому проблема розвитку природних здібностей дитини є дуже важливою.

Значення взаємозв'язку і наступності у вихованні дітей дошкільного і шкільного віку висвітлювали у своїх працях К. Ушинський, А. Макаренко, В. Сухомлинський, Н. Лубенець та інші видатні педагоги. Значний внесок у розвиток проблеми наступності зробили такі вчені, як Б. Ананьєв, Л. Виготський, В. Давидов, Л. Занков, В. Крутецький, Н. Менчинська, Р. Нємов, С. Тихєєва та багато інших.

В. Сухомлинський зазначав: «Школа не повинна вносити різкого перелому в життя дітей. Нехай, ставши учнем, дитина продовжує робити сьогодні те, що робила вчора. Нехай нове 3'являється в іiі житті поступово і не приголомшує лавиною вражень». Н. Лубенець стверджувала, що «..починати виховання дітей зі школи - означає зводити будівлю на піску i без фундаменту». Своєрідним уточненням цього положення $\epsilon$ міркування Є. Тихєєвої, яка вважала, що «старший ступінь дитячого садка на одну третину вже школа, а молодший ступінь школи на одну третину дитячий садок» [5, с. 67].

Mета статmi - висвітлити проблему наступності у теорії та практиці дошкільної та початкової ланок освіти.

Наступність - поняття багатогранне. Це і соціальна адаптація дитини в нових умовах, $\mathrm{i}$ необхідний рівень розвитку творчої уяви, і формування певних комунікативних умінь. Наступність містить як елемент підготовку дитини до навчання в школі, тобто оволодіння необхідним обсягом знань і умінь.

Педагогічний досвід дозволяє говорити про наступність як двосторонній процес. Школа не будує своєї роботи 3 «нуля», а «підхоплює» досягнення дитини-дошкільника $\mathrm{i}$ розвиває накопичений ним потенціал.

Сучасна ситуація вимагає вироблення спільних підходів до оцінювання готовності дитини до школи 3 позиції самоцінності дошкільного дитинства (А. Запорожець, Д. Ельконін) i забезпечення нормального переходу до шкільного навчання. Оцінка грунтується на розумінні того, що до змісту готовності входить досягнення дітьми певного рівня фізичного, пізнавального, соціального розвитку й оволодіння передумовами навчання: уміння управляти поведінкою, планувати і контролювати свої дії, взаємодіяти 3 однолітками і дорослими, слухати вчителя і виконувати його вимоги. Для реалізації на 
практиці наступності потрібні розроблення комплексу організаційних заходів, нових нормативних актів, приведення у відповідність із стандартами освіти великої кількості навчально-методичних посібників, удосконалення підготовки та перепідготовки педагогічних кадрів [4].

Наступність, що створює загальний сприятливий фон для фізичного, емоційного й інтелектуального розвитку дитини в ДНЗ і початковій школі, буде сприяти збереженню і зміцненню її фізичного і психічного здоров'я, а це - найважливіше завдання освіти і їі основний результат.

На сучасному етапі набуває актуальності проблема створення прогресивної системи безперервної освіти. При цьому дошкільна освітня установа забезпечує базисний розвиток здібностей дитини, а початкова школа, використовуючи досвід дитячого садка, сприяє його подальшому розвитку.

Нині у низці дошкільних освітніх установ виникає негативна тенденція дублювання цілей, завдань, форм і методів початкової школи. Зміст дошкільної освіти будується у «шкільній логіці» - логіці майбутніх навчальних предметів.

Практикується раннє навчання дітей письма, читання, ускладненої для дошкільників математики тощо. Створюється неправомірна диспропорція у провідних змістовних лініях освіти, що полягає в перевазі пізнавального розвитку над художньо-естетичним, фізичним i соціально особистісним. Гра й інші специфічні для цього віку види діяльності витісняються заняттями, які стають панівною формою навчання та виховання. При цьому ігноруються об'єктивні вікові закономірності розвитку дитини, характерні для дошкільного віку, а отже, й інтереси самої дитини.

Дані медицини свідчать про те, що подібне раннє навчання призводить до перевтоми та перевантажень маленьких дітей, негативно позначається на стані їхнього здоров'я, провокує неврози та інші небажані явища при переході до шкільної освіти. Перехід дитини з дитячого садка у школу є важливим етапом іiі життя, який пов'язаний не лише зі зміною середовища іiі розвитку, а й із відповідними процесами самоусвідомлення, зіткненням із новими проблемами, відкриттям у собі нових можливостей тощо. Одним дітям це додає піднесеного настрою, відчуття виходу на новий життєвий щабель, іншим ностальгії за звичним життям у дитячому садку, часто породжує стресові стани. Тому важливо, щоб у дошкільному закладі, сім'ї дитині допомогли усвідомити, що дитячий садок і школа є ланками єдиної системи освіти і виховання, а все те, що чекає дитину у школі, $є$ продовженням того, чим займалася, що опановувала вона раніше. Не менш важливим є те, щоб із перших днів перебування в школі вона на конкретних реаліях переконувалася в цьому.

Початкова освіта - перший освітній рівень, який закладає фундамент загальноосвітньої підготовки учнів. Відповідно до можливостей дітей молодшого шкільного віку початкова школа, зберігаючи наступність із дошкільною ланкою, має забезпечити подальше становлення дитячої особистості, іiі інтелектуальний, соціальний і фізичний розвиток [1, c. 53].

Як зазначають фахівці, проблеми наступності мають декілька наукових аспектів, зокрема: психологічний, що пов'язаний із вивченням природного логічного зв'язку в розвитку дітей; педагогічний, спрямований на забезпечення поняття «наступність» новим суттєвим змістом; методичний, що стосується визначення послідовних логічних зв'язків у меті, завданнях, змісті, методах, організаційних формах і засобах навчання і виховання.

Досвід, накопичений у нашій країні та за кордоном, надає змогу говорити, що більш раннє навчання дітей позитивно впливає на становлення їхніх фізичних і духовних сил. Безумовно, для цього слід створити необхідні умови. Головне - турбота про фізичне, психічне і соціальне благополуччя дитини. Усе це можливе за дотримання принципу наступності дошкільної та початкової освіти.

Наступність ураховує рівень розвитку дитини, 3 яким вона прийшла до школи, забезпечує органічне, природне продовження розвитку, виховання та навчання, 
започаткованих у дошкільному віці, створює умови для успішного переходу молодшого школяра в основну школу.

3 боку дошкільних навчальних закладів наступність повинна виявлятися не тільки в підготовці дитини до школи, а й у забезпеченні ії загального психічного розвитку, з боку школи - передбачати продовження загального психічного розвитку дитини на основі максимального використання того позитивного, що дитина набула в дошкільному віці. Наступність у роботі дитячого садка та початкової школи - це не тільки традиційна наступність у змісті, методах, формах і прийомах, перш за все, - бачення та реалізація наступності в лініях, основних аспектах розвитку особистості дошкільника та молодшого школяра. Це двобічний процес, коли зберігається самоцінність дошкільного дитинства і створюються передумови для успішного формування навчальної діяльності першокласників.

Упровадження психолого-педагогічних принципів, які б забезпечували наступність між дошкільною та початковою ланками загальної освіти вимагає розгляду двох взаємопов'язаних аспектів: анатомо-фізіологічного (який спрямований на виявлення анатомо-фізіологічних особливостей дітей дошкільного і молодшого шкільного віку 3 метою їх урахування під час розроблення теоретичних основ наступності між дошкільною та початковою ланками загальної освіти) і психолого-педагогічного (який пов'язаний із вивченням закономірностей психічного розвитку дитини на перехідному етапі від дошкілля до шкільництва задля урахування під час розроблення мети, змісту, методів, форм і засобів наступності в навчанні й вихованні дітей дошкільного та молодшого шкільного віку).

Критерієм нормальної адаптованості дитини до шкільного навчання є іiї позитивне ставлення до школи, розуміння пояснюваного вчителем навчального матеріалу, самостійність, здатність зосереджувати увагу під час виконання завдань, охоче виконання громадських обов'язків і доброзичливе ставлення до однокласників. Усе це засвідчує належну ефективність процесу соціальна-психологічної адаптації до школи - активного пристосування дитини до класу, вчителя, свого місця у школі.

Про наявність внутрішньої позиції школяра свідчать позитивне ставлення до вступу до школи як до природного й обов'язкового явища в своєму житті; уявлення про школу та шкільний зміст занять, інтерес до занять з навчання грамоти і лічби; надання переваги колективним заняттям над індивідуальними; позитивне ставлення до вимог дисциплінованої поведінки, очікування оцінки; визнання авторитету вчителя. 3 огляду на це в роботі зі старшими дошкільниками вихователі повинні уважно аналізувати особливості їхнього розвитку, прогнозувати імовірні проблеми в школі, спрямовувати зусилля на розвиток їхніх знань, умінь і навичок, що максимально полегшило б адаптацію в шкільному середовищі.

Наступність потрібно розглядати як один із основоположних принципів неперервної освіти, завданням якої є забезпечення цілісного розвитку особистості в навчанні дітей на перших двох ланках системи неперервної освіти. Таке розв'язання поставленого завдання вимагає розв'язати проблему наступності у підготовці фахівців для дошкільних навчальних закладів та початкової школи.

Наступність у системі неперервної педагогічної освіти має внутрішню - змістову (це зміст знань, умінь і навичок, які передаються) і зовнішню - процесуальну, організаційну сторони (забезпечується організацією передачі знань, умінь і навичок) [2, с. 18]. Тому у формуванні педагога вирішальну роль, окрім змісту освіти, відіграють освітнє середовище університету, організація освітнього процесу, інноваційні педагогічні технології, сучасні підходи до організації навчальної, наукової, самостійної роботи студентів тощо.

Основою змісту й оцінки якості освітньої та професійної підготовки фахівців незалежно від рівнів акредитації та форм навчання $\epsilon$ стандарт, відображений у відповідних освітньо-професійних програмах, навчальних планах, структурно-логічних 
схемах підготовки, програмах навчальних дисциплін, інших нормативних документах, навчальній та навчально-методичній літературі.

Формою відображення змісту є навчальні предмети, інтегровані курси, які мають відповідати рівневі підготовки учнів і цілям їх вивчення [6, с. 49].

У початковій школі у більшості предметів провідним компонентом змісту $\epsilon$ застосування способів діяльності, тобто широкого кола різноманітних умінь і навичок. Однак, вони базуються на усвідомлених знаннях про те, чому і як їх треба виконувати. Наприклад, ознайомлення з довкіллям, етика і культура поведінки, валеологія переважно формують досвід емоційно-ціннісних ставлень і взаємозв'язків дитини: гуманні почуття, потреби, позитивний досвід спілкування i поведінки [3, c. 72], формування яких розпочинається в умовах дошкільного закладу.

Тому наступність у дошкільній i початковій освіті забезпечує вивчення таких навчальних дисциплін, як дитяча література, основи культури і техніки мовлення, методик викладання: математики, української мови, російської мови, іноземної мови.

Підготовка педагогічних кадрів дошкільної та початкової освіти щодо реалізації принципу наступності в умовах університету може забезпечуватись також шляхом поєднання спеціальності «Дошкільна освіта» і «Початкова освіта». Таке поєднання надає змогу підготувати педагогів, діяльність яких буде грунтуватись на компетентністному підході до формування особистості дитини, що в свою чергу передбачає не тільки когнітивний і операційно-технологічний складники, але й мотиваційну, етичну, соціальну, поведінкову сторони (результати освіти, знання, уміння, систему ціннісних орієнтацій).

\section{Література}

1. Вашуленко О. Питання наступності в педагогічній теорії / О. Вашуленко // Педагогіка і психологія. - 2005. - №4. - С. 49-58. 2. Енциклопедія освіти / В. Г. Кремень // Акад. пед. наук України; головний ред. В. Г. Кремень - К. : Юрінком Інтер, 2008. - С. 10-40. 3. Зязюн І. А. Філософія неперервної освіти: Здобутки, пошуки, проблеми / I. А. Зязюн // Матеріали Міжнародної науково-практичної конференції: у 6-и книгах, кн. 1. - Чернівці: Митець, 1996. 152 с. 4. Кузьмінський А. І. Організаційно-педагогічні основи безперервної освіти педагогічних кадрів: автореф. дис... канд. пед. наук / А. І. Кузьмінський - К., 1997. - 19 с. 5. Лубенец Н. Д. Общественные и семейные начала в детском возрасте / Наталия Дмитриевна Лубенец // Дошкольное воспитание. - 1911. - № 2. - С. 62-70. 6. Савченко О. Я. Дидактика початкової школи: підручник [для студентів педагогічних факультетів] / О. Я. Савченко - К. : Абрис, 1997. - 416 с.

УДК 37.035

Л. В. Кужільна, кандидат філол. наук, доцент, ДВНЗ «Криворізький національний університет»

\section{ІГРОВЕ ЕМОЦІЙНО-ДІЯЛЬНІСНЕ НАВЧАННЯ ЯК ПЕДАГОГІЧНА ТЕХНОЛОГІЯ}

Кужільна Л. В. Ігрове емоційно-діяльнісне навчання як педагогічна технологія.

У статті здійснено аналіз теоретичних основ методики М. Зайцева як педагогічної тенології, що задіює безліч сенсорних каналів, передбачає подання інформації блоками, підкреслює значимість опорних сигналів. Доведено, що розробки М. Зайцева дозволяють організувати розвивальний простір для дітей дошкільного і шкільного віку, надають педагогам змогу творчо підходити до готових програм, змісту освіти, способам його подання(методам і прийомам); вносити в роботу елементи дослідницької діяльності, кардинально скорочувати час оволодіння навиками читання i грамотного письма.

Ключові слова: складова теорії навчання, побуквене читання, розвиваючий простір, кубики.

Кужильна Л. В. Игровое эмоционально-деятельностное обучение как педагогическая технология.

В статье осуществлен анализ теоретических основ методики Н. Зайцева как педагогической технологии, которая задействует множество сенсорных каналов, предусматривает значимость опорных сигналов. Разработки Н. Зайцева позволяют организовать развивающее пространство для 